\title{
The Influence of Degree of Maturity on the Quality of Canned Pigeonpeas
}

\author{
F. Sánchez Nieva ${ }^{1}$ \\ INTRODUCTION
}

The quality of canned pigeonpeas (Cajan cajan $L$ ) can be improved by the use of proper processing techniques and the control of processing variables. Sánchez et al $(1)^{2}$ showed that discoloration of the brine and the development of objectionable haziness could be avoided by inactivating the enzyme system of the pigeonpeas before shelling. The length of the blanching treatment, the use of copper or iron in the processing equipment, and excessive head-space were found by Sánchez et al. (2) to affect the color and turbidity of the brine. The other important factor which determines the quality of canned pigeonpeas is the degree of maturity which affects color, flavor, and texture.

The degree of maturity plays a very important role in the grading of canned pigeonpeas, and three quality criteria: The uniformity of the color as affected by the predominance of the green pigment; the condition of the brine with respect to viscosity, turbidity, suspended material and color; and the character influenced by the number of maturity cracks and sprouted peas, are all directly affected by the degree of maturity.

The importance of maturity as a quality-determining factor in the canning of vegetables like peas, southern field peas, and lima beans has been established. Extensive work has been reported in the literature on the development of methods for the objective measurement of the maturity of peas (Pisum sativum $L$ ). Makower ( 3 ) reviewed most of the tests developed to measure the maturity of peas, such as tenderometer readings, alcoholinsoluble solids, total solids, specific gravity determination, and starch. Malcolm et al. (4) studied the suitability of these indices to measure the maturity of field peas (Vigna sinensis).

The effect of maturity on the quality of canned peas has also been studied extensively. Woodruff et al. (5) showed that the maturity of southern field

${ }_{1}^{1}$ Technical Director, Food Technology Laboratory, Agricultural Experiment Station, University of Puerto Rico, Rio Piedras, P.R. The author wishes to express his gratitude to the various members of the staff of the Food Technology Laboratory for the assistance and cooperation during the course of this study. Special recognition is given to M. A. Gonzalez, J. R. Benero, and I. Hernández for their assistance in the operation of the pilot plant; to G. Colom Covas, who was in charge of the experimental planting used in this work; and to N. Díaz and M. Matos for analyzing and grading some of the samples.

2 Italic numbers in parentheses refer to Literature Cited, p.231. 
peas directly affected the quality, especially the color and appearance of the canned product. The color and appearance of the peas canned while in the fully mature, but green stage were scored more than twice as high as for overmature or white peas. The overmature peas were darker in color and the liquor was very cloudy, with suspensions of pasty gelatinous particles. In the canning of field peas Malcolm et al. (4) showed that cloudiness of the liquor and gelation were related to maturity. The relation of maturity to yield and quality of raw and canned peas, corn, and lima beans was studied by Kramer (6).

Objective maturity indices for pigeonpeas was studied by Sánchez et al. (7). Alcohol-insoluble solids, specific gravity, starch, total solids, and moisture were shown to be reliable maturity indices for pigeonpeas. A high correlation was shown to exist between the intensity of the green pigment or number of green peas in any sample, and starch, alchohol-insoluble solids, total solids, moisture, and specific gravity. Although the maturity of pigeonpeas can be determined easily by the use of any of the tests indicated, canners still purchase pigeonpeas by weight. Since mature peas weigh more than tender or fully developed green peas, farmers prefer to harvest the peas at a maturity which may not be the optimum for the canning of a high-quality pack. It was the purpose of this work to show the importance of maturity in the processing and canning of pigeonpeas, and the influence that the degree of maturity has on the quality of the canned product.

\section{MATERIALS AND METHODS}

\section{PROCESSING METHODS AND SAMPLING}

Pigeonpeas of the Kaki and Saragateado varieties were processed in a pilot-plant line with a capacity of 500 pounds of pods per hour. Only one variety was processed for each set of experiments reported. The pods were steamed to inactivate the enzyme system, as described by Sánchez et al. (1) and shelled in a huller having a capacity of 500 pounds per hour. The shelled peas were flumed from the huller to a rod-reel washer with rods spaced at 5/16 of an inch. The rod-reel washer graded the peas into two sizes, those larger than the rod spacings which will be designated as "primary" peas, and those smaller that went through the rods which will be designated as "secondary" peas. Both types of peas were collected and weighed separately for the determination of yields. Only primary peas were used for canning.

The primary peas were transferred in trays to a picking-belt where pickers removed defective peas only. After picking, the peas were blanched in water at $185^{\circ} \mathrm{F}$. for 5 minutes. A stainless-steel rotary blancher with dual temperature control was used. The blanched peas were cooled in a rod-reel 
washer and transferred to a second picking-belt where defective units which passed the first inspection, as well as mashed or crushed peas, were removed. The peas were packed in plain tin cans with C-enameled ends, 11.5 ounces to the can. Boiling 2-percent brine was added and the cans were closed and processed for 35 minutes at $240^{\circ} \mathrm{F}$., followed by rapid cooling in water to $100^{\circ} \mathrm{F}$. All cans were stored at $85^{\circ} \mathrm{F}$. for 15 days before being analyzed and inspected.

To prepare the samples listed in table 1 , pigeonpeas consisting of about

TABLE 1.-Effect of malurity on the percentage of splits, drained weight, volume and viscosity of brine, and grade classification of canned pigeonpeas

\begin{tabular}{|c|c|c|c|c|c|c|c|}
\hline \multicolumn{2}{|c|}{ Alcohol-insoluble solids } & \multirow{2}{*}{ Yellow peas } & \multirow{2}{*}{ Maturity cracks } & \multirow{2}{*}{$\begin{array}{c}\text { Drained } \\
\text { weight }\end{array}$} & \multirow{2}{*}{$\begin{array}{c}\text { Volume of } \\
\text { brine }\end{array}$} & \multirow{2}{*}{$\begin{array}{l}\text { Viscosity } \\
\text { of brinc }\end{array}$} & \multirow{2}{*}{ Gradel } \\
\hline Dry basis & Wet basis & & & & & & \\
\hline Percent & Percent & Percent & Percent & Ounces & Milliliters & $\begin{array}{l}\text { Flozp in } \\
\text { seconds }\end{array}$ & \\
\hline 30.13 & 22.4 & 51.4 & 80.0 & 17 & 100 & 25.6 & $\mathbf{S}$ \\
\hline 27.33 & 20.45 & 46.1 & 27.9 & 17 & 138 & 33.4 & $\mathbf{S}$ \\
\hline 28.75 & 21.49 & 31.3 & 22.1 & 16 & 160 & 39.6 & $\mathbf{S}$ \\
\hline 28.64 & 21.45 & 30.6 & 21.9 & 16 & 170 & 25.8 & $\mathbf{C}$ \\
\hline 27.80 & 20.79 & 28.5 & 21.0 & 15 & 200 & 21.7 & $\mathrm{C}$ \\
\hline 27.35 & 20.44 & 23.6 & 19.2 & 15 & 190 & 20.2 & B \\
\hline 26.99 & 20.51 & 21.0 & 18.1 & 16 & 200 & 16.9 & B \\
\hline 25.62 & 19.34 & 13.6 & 10.0 & 15 & 185 & 16.2 & $\mathbf{B}$ \\
\hline 24.88 & 18.94 & 13.2 & 11.2 & 14 & 190 & 12.8 & $\mathrm{~B}$ \\
\hline 25.45 & 19.47 & 7.7 & 6.0 & 14 & 205 & 11.7 & $\mathbf{A}$ \\
\hline 24.38 & 18.93 & 6.9 & 5.8 & 14 & 210 & 11.5 & A \\
\hline 23.17 & 17.90 & 3.1 & 3.2 & 14 & 210 & 9.3 & $\mathbf{A}$ \\
\hline 23.62 & 18.27 & .6 & 3.1 & 13 & 225 & 10.6 & A \\
\hline
\end{tabular}

$1 \mathrm{~A}, \mathrm{~B}$, and $\mathrm{C}$ designate the grade of the product in accordance with the standards of the Commonwealth of Puerto Rico Department of Agriculture: $\mathbf{S}=$ Substandard.

50-percent fully mature and 50-percent overripe yellow peas were brinegraded after blanching, using a brine of specific gravity 1.11. Yellow peas in the floaters were removed by hand; so were green peas in the sinkers. Green and yellow peas were then mixed in such proportion as to obtain the percentage of yellow peas in the canned product as indicated in table 1 . The peas were canned and processed as indicated.

To determine the effect of maturity on shelled-out percentage and yields, pigeonpeas of the Kaki variety were harvested at different stages of development as follows: Eighteen rows each containing from 102 to 143 trees were randomized for sampling. When they attained the stage where fully developed peas were more abundant, three rows were harvested, all pods being 
picked regardless of the stage of development, except the dry. Three rows selected at random were then harvested in the same way at intervals of 3 , $6,9,13$, and 16 days after the first harvest. The peas from each row were delivered to the Laboratory the same day in which they were picked and were stored at $45^{\circ} \mathrm{F}$. until processed. The peas from each row were processed separately as already described. Average values for the three rows harvested at each time interval are given in table 2.

\section{ANALYTICAL METHODS}

Alcohol-insoluble solids were determined by the AOAC procedure ( 8 ) modified as follows: The sample for analysis was prepared by dispersing a known weight of pigeonpeas with an equal weight of water in a Waring

TABLE 2.-Shelled-out percentage and yields of No. 2 cans obtained from processing pigeonpeas at several stages of maturity as indicated by the alcohol-insoluble content

\begin{tabular}{c|c|c|c|c|c}
\hline $\begin{array}{c}\text { Alcohol-insoluble } \\
\text { solids } \\
\text { (percent) }\end{array}$ & $\begin{array}{c}\text { Primary peas } \\
\text { from pods }\end{array}$ & $\begin{array}{c}\text { Secondary peas } \\
\text { from pods }\end{array}$ & $\begin{array}{c}\text { Total shelled } \\
\text { out }\end{array}$ & $\begin{array}{c}\text { No. 2 cans } \\
\text { produced from } \\
\text { 100 1. pods } \\
\text { processed }\end{array}$ & $\begin{array}{c}\text { Cases of 24-No. } \\
\text { 2 cans produced } \\
\text { from 100 lb. } \\
\text { processed }\end{array}$ \\
\cline { 2 - 4 } 23.19 & Percent & Percent & Percent & Number & Number \\
24.84 & 25.92 & 6.77 & 29.34 & 28.57 & 1.19 \\
26.51 & 35.31 & 6.46 & 35.35 & 33.50 & 1.40 \\
27.39 & 37.55 & 4.09 & 40.41 & 41.20 & 1.72 \\
29.39 & 40.44 & 4.23 & 42.66 & 47.20 & 1.97 \\
28.84 & 39.53 & 4.03 & 44.67 & 49.1 & 2.05 \\
30.17 & 43.13 & 3.66 & 46.79 & 51.0 & 2.00 \\
\hline
\end{tabular}

blendor. About $15 \mathrm{gm}$. of this mixture are transferred to a $600-\mathrm{ml}$. beaker and extracted for 30 minutes with 80-percent alcohol. After the extraction was complete, the sample was filtered, the solids were washed with alcohol until the filtrate was free from coloring matter, and the washed solids were transferred to an aluminum dish and dried at $100^{\circ} \mathrm{C}$. for 2 hours.

To measure the color of the brine, $30 \mathrm{ml}$. of brine were taken from a can immediately after opening and placed in a Hellige No. 8010-50 cup, 50-mm. viewing depth. The color of the brine was measured by transmission in a Hunter color and color-difference meter calibrated for $T=99, a=0$, $\boldsymbol{b}=\mathbf{0}$. Color values are calculated from the equation: Color of brine $=$ $\sqrt{T^{2}+a^{2}+b^{2}}$, where $T, a$, and $b$ are the values read directly from the meter scale. Since the color is measured by transmittance, high values for color indicate lighter colored and less turbid brines.

Turbidity of the brine was measured in the Klett-Summerson colorimeter using a No. 47 blue filter. A sample of the brine was taken from a can im- 
mediately after opening and diluted with an equal volume of distilled water. A 10-ml. sample was placed in the colorimeter tube and the transmittance measured. Turbidity is expressed as Klett-Summerson scale units as read directly from the meter scale. High values of turbidity indicate highly turbid brines, while low values indicate brines of low turbidity.

The viscosity of the brine was mcasured in a glass pipette with a restricted tip by measuring the time taken for a known volume of brine to flow from the pipette. All measurements were made at $27^{\circ} \mathrm{F} .+1^{\circ}$. Viscosity values are expressed in seconds of flow.

The grade and score of the canned sample for the different quality criteria measured were determined by accordance with the standards issued by the Commonwealth of Puerto Rico Department of Agriculture.

\section{RESULTS AND DISCUSSION}

In the study of the effect of maturity on product quality, two approaches are possible: To determine the maturity of the raw peas before canning, or to base the study on the maturity of the canned product itself. The first approach offers the advantage that the different quality criteria can be correlated to the maturity of the fresh peas, and such data would be of great value in predicting the quality of the pack when the maturity of the raw peas is known. For the purpose of this work, to study the effect of maturity on product quality, such an approach has the disadvantage of introducing an uncontrollable error because of the variation in composition usually encountered in the processing of pigeonpeas.

It is preferable to use the second approach for determining the maturity of the canned product, and correlating it with the different quality criteria. Knowing the maturity of the peas in the can examined makes it possible to more precisely correlate the effect of maturity with the different quality criteria used in grading the canned product, and at the same time, use fewer samples to obtain the desired data. Throughout this work, the effect of maturity on the quality of the canned product is based on the maturity of the peas directly in the can under study.

Several measures can be used to determine the maturity of pigeonpeas. Sánchez et al. (7) showed that correlation coefficients significant at the 1-percent probability level were obtained for starch, alcohol-insoluble solids, total solids, and specific gravity when correlated with the number of green peas in any sample of fresh pigeonpeas. Of the different maturity indices proposed by Sánchez, alcohol-insoluble solids have been found to be the more precise for the determination of maturity of canned pigeonpeas. This determination is less subject to analytical errors than the determination of starch. Specific gravity measurements are not adequate, since the liquor adsorbed by the processed peas makes it impossible to obtain reliable meas- 
urements. Total-solid determinations are likewise influenced by the quantity of liquor adsorbed by the drained peas, which becomes greater the more mature the peas are.

It was shown by Sánchez el al. (7) that, as pigeonpeas mature, the alcoholinsoluble solids, and the number of yeallow peas increase. Therefore, an increase in the number of yellow peas indicates that the sample is more mature. If alcohol-insoluble solids is a reliable indication of maturity in canned pigeonpeas, the increase in the number of yellow peas should be paralleled by a corresponding increase in the value for the alcohol-insoluble solids. That this holds true for the canned product, was shown when the values for alcohol-insoluble solids given in table 1 were plotted against the corresponding number of yellow peas in the can.

A straight-line relationship was obtained which is shown in figure 1. The experimental correlation coefficient found for these values was 0.831 which is significant at the 1-percent probability level. The high correlation between the alcohol-insoluble solids of canned pigeonpeas and the number of overripe peas in the can permits us to use either of these two measures to indicate the maturity of the product in the can.

Data to show the effect of maturity on the number of splits, drained weight, volume of brine, and grade of canned pigeonpeas are given in table 1. As the percentage of alcohol-insoluble solids increases, the percentage of yellow peas in the can shows a parallel increase, and the percentage of peas with broken skins and with cracks greater than one-sixteenth of an inch also increases. The percentage of cracked peas is directly related to maturity as can be seen from figure 2, where the regression equation for the increase in the percentage of splits with alcohol-insoluble solids is shown. The data in table 1 also show that drained weight increases with maturity. The increase in drained weight is due to the higher absorption of the liquor by the more starchy peas. As the peas become more soaked, not only drained weight increases, but the peas swell, become more densely packed in the can, and mashing and rupturing of the skin results.

As more liquor is absorbed by the more mature peas the volume of the brine decreases and the viscosity increases. The effect of maturity on the volume and viscosity of the brine is shown in figures 3 and 4 .

Maturity also has a direct effect on the color and turbidity of the brine. The change in the color and turbidity of the brine with the increase in the percentage of yellow peas in the can is shown by the data in table 3 and by the curves in figures 5 and 6 . As more ripe or overmature peas are canned, the brine becomes darker and more turbid.

Since the number of cracked peas in the can, the viscosity, turbidity, and color of the brine, as well as the number of yellow peas in the can, enter into consideration in grading the product, as maturity increases, it is reasonable 
to expect that the quality of the canned product will be adversely affected. The characteristics of the drained liquor are first considered in grading canned pigeonpeas. The viscosity, turbidity, quantity of suspended matter, and

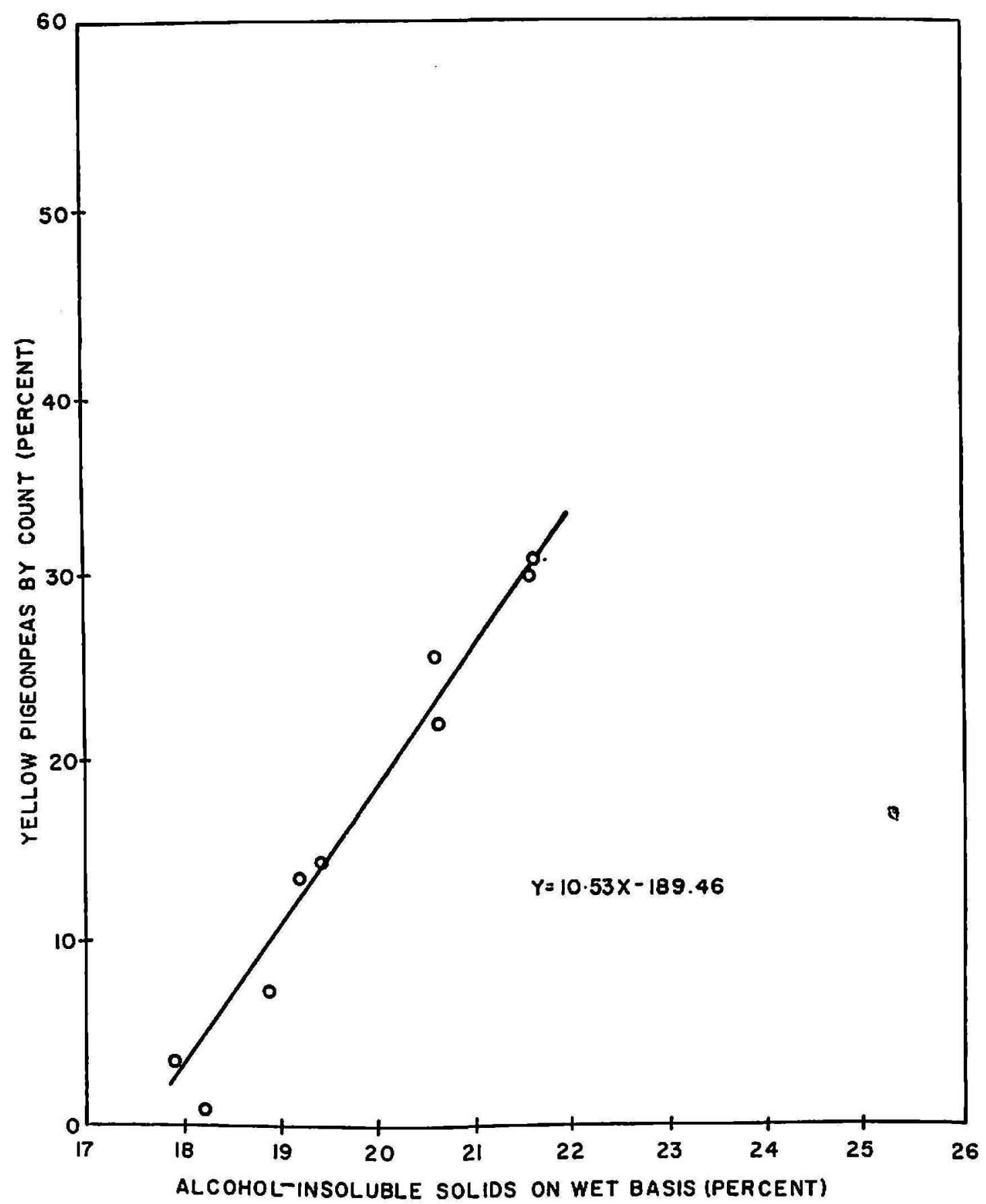

Fir. 1.-Relation between number of overmature yellow pigeonpeas in the can and alcohol-insoluble solid content.

color of the brine are taken into consideration in rating the product. Fancy peas should have a brine of low viscosity and turbidity, free of suspended matter and almost colorless. Color of the drained peas is another factor con- 
sidered in grading the product. Color with respect to the predominance of the green pigment also determines the grade, as fancy peas should have a green color typical of processed green peas, and the number of yellow peas

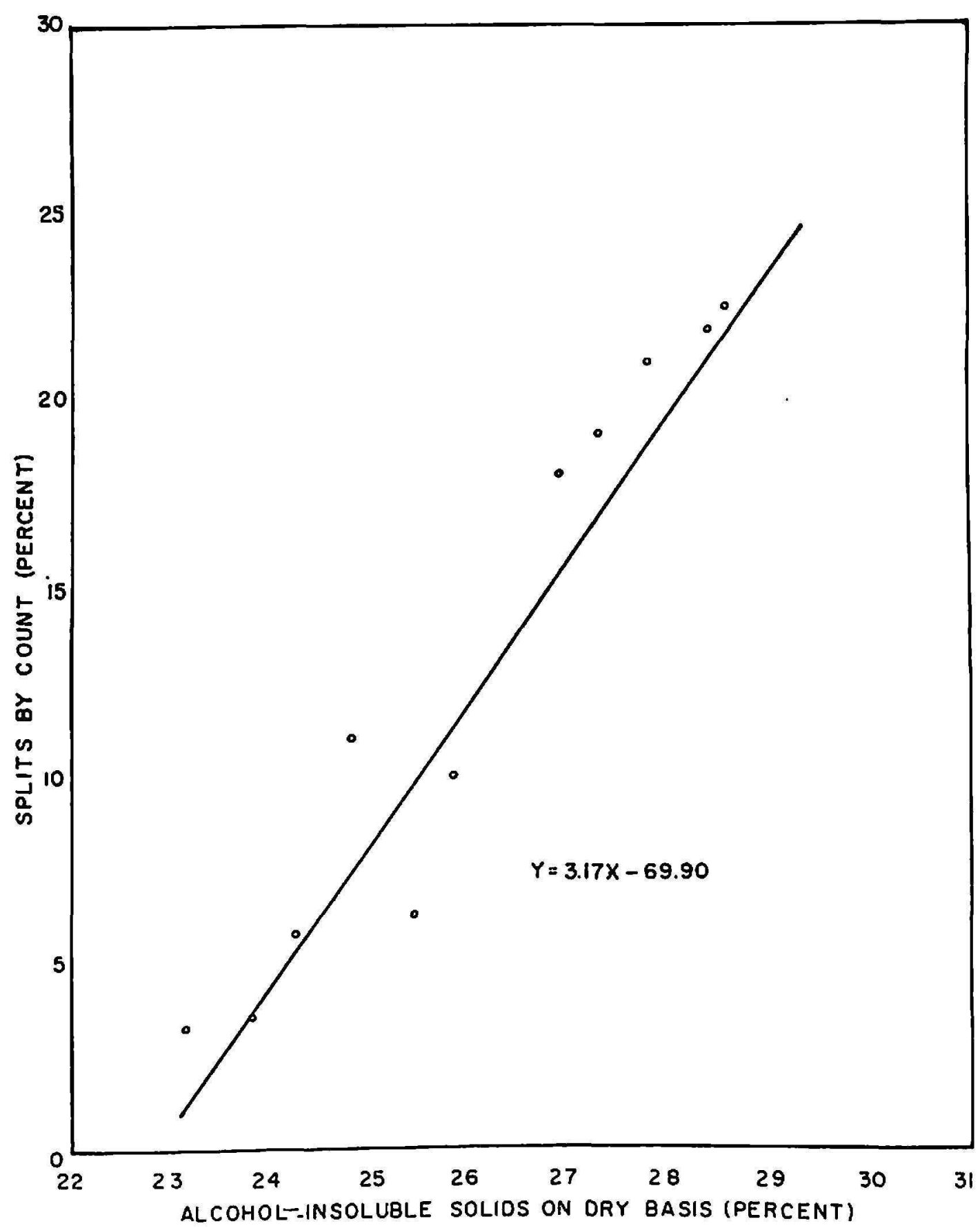

FIs. 2.-Relation hetween maturity and percentage of splits in canned pigeonpeas.

should not be so great as to affect the uniformity of the product from the color standpoint. Another factor taken into consideration in grading the product is the character of the peas, which is a measure of the percentage of overripe peas and of the splits. 
Since all the quality criteria mentioned above have been shown to be dependent on the maturity of the pigeonpeas, as indicated by the percentage of yellow peas, it is to be expected the grade of the canned product should

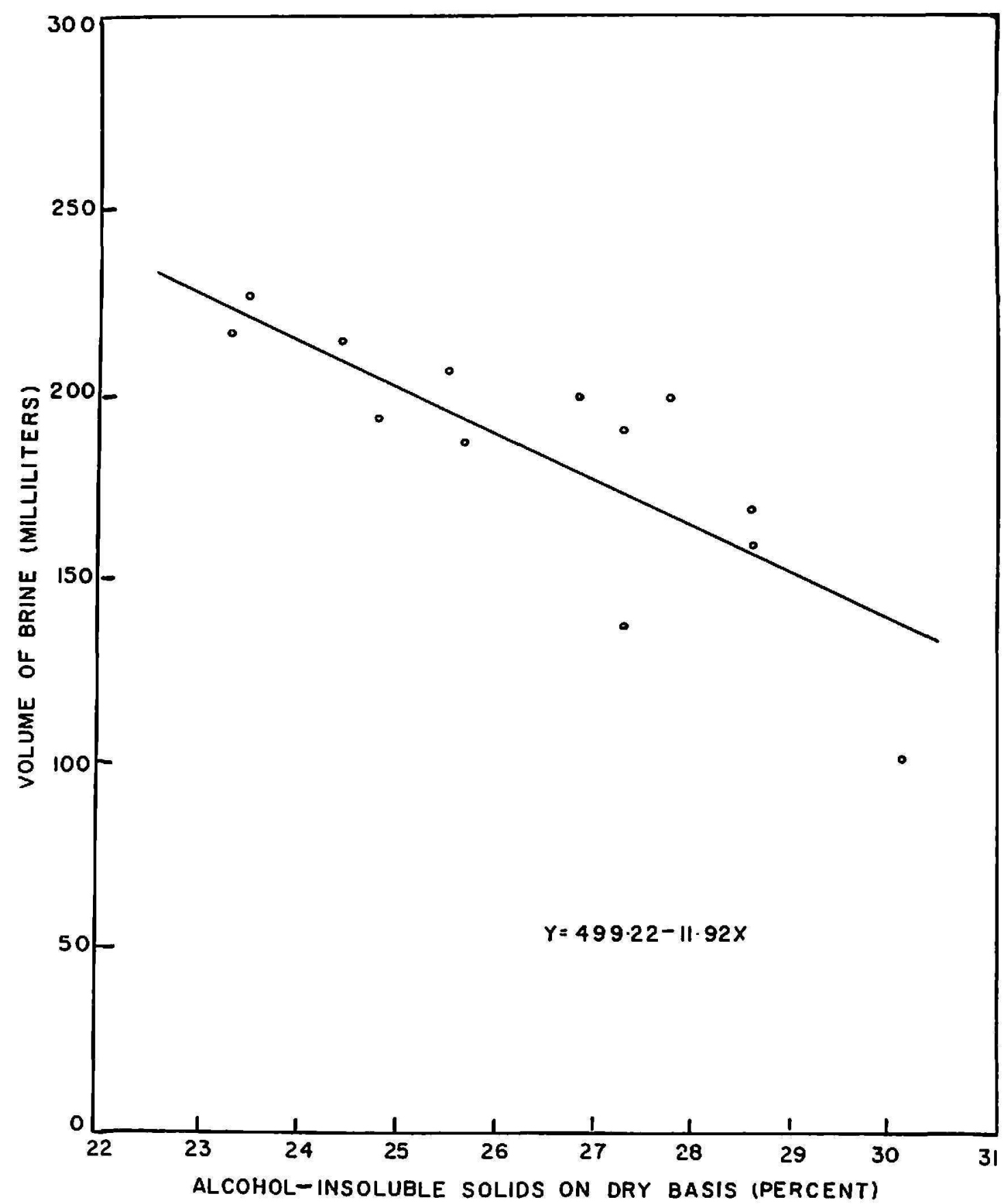

FIG. 3.-Relation between alcohol-insoluble solids and volume of brine in canned pigeonpeas.

decrease as maturity increases and as the number of yellow peas in the can increases.

The effect of the increase in the number of yellow peas in the can on the 
grade given to the canned product can be seen from the data in tables 1 and 4. There is a direct relationship between grade and maturity. The quality and, therefore, the grade of the product decreases as the number of yellow peas in the can increases. If the data in table 4 are rearranged to show the range of values obtained for each grade, as given in table 5, it is

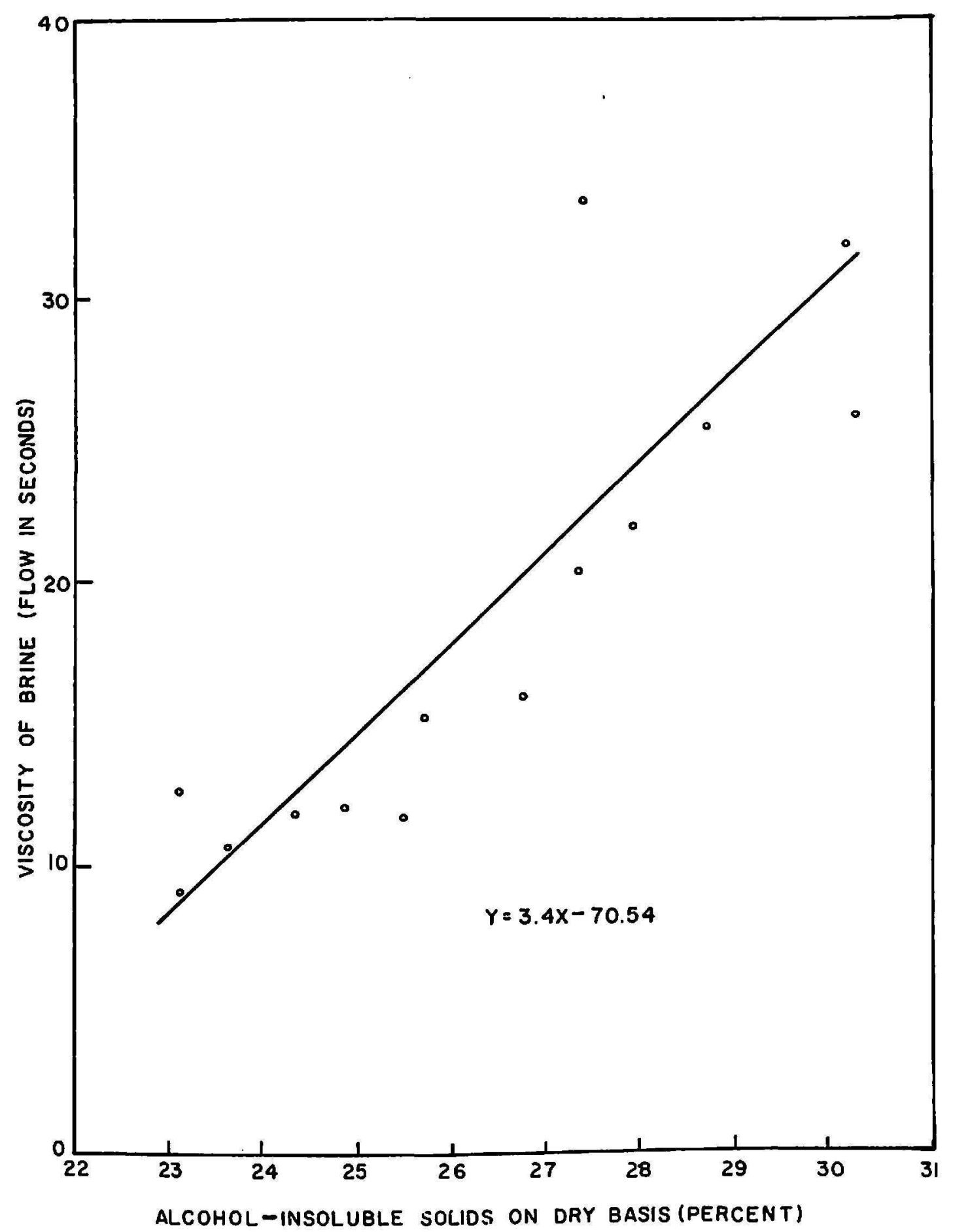

FIg. 4.-Relation between alcohol-insoluble solids and viscosity of brine of canned pigeonpeas. 
clearly seen that, for an A-grade product, the alcohol-insoluble solid content and the number of yellow peas in the can should not exceed certain limits.

Likewise, all samples graded in the $\mathrm{B}$ and $\mathrm{C}$ groups had an alcohol-insoluble-solid content and percentage of yellow peas within a certain range. It should be noted that there is an overlapping in the percentage of yellow peas and alcohol-insoluble solids for grades B and C. Since grade determination is completely based on subjective measurements of the different quality criteria, it is difficult to clearly establish a difference between borderline samples in the lower grades. In such cases the presence of defects

TABLE 3.-Content of yellow peas in samples of pigeonpeas, and color and turbidity of brine from same can on which the count was made

\begin{tabular}{c|c|c}
\hline $\begin{array}{c}\text { Ycllow peas in the cans in } \\
\text { percentage by count }\end{array}$ & $\begin{array}{c}\text { Turbidity of brine in Klett- } \\
\text { Summerson units }\end{array}$ & $\begin{array}{c}\text { Color of brine } \\
\sqrt{\left(T^{2}+a^{2}+b^{2}\right)}\end{array}$ \\
\hline 17.11 & 195.5 & 41.45 \\
11.17 & 212.8 & 35.48 \\
8.90 & 193.5 & 40.90 \\
7.84 & 186.3 & 41.80 \\
17.29 & 251.7 & 34.63 \\
18.62 & 182.0 & 40.95 \\
18.43 & 283.5 & 33.02 \\
16.92 & 203.0 & 42.67 \\
19.39 & 245.0 & 36.40 \\
27.11 & 268.8 & 34.52 \\
18.99 & 241.3 & 37.40 \\
33.71 & 304.0 & 31.77 \\
22.32 & 274.2 & 33.05 \\
22.45 & 284.0 & 35.85 \\
24.30 & 243.0 & 36.45 \\
24.90 & 287.0 & 30.60 \\
25.39 & 302.5 & 28.70 \\
\hline
\end{tabular}

taken into consideration when the product is graded may determine the grade, regardless of maturity.

The data in tables 4 and 5 should not be taken as indicative of the limits of alcohol-insoluble solids and percentage of yellow peas for each of the grades A, B, and C. This is true only for the experimental samples studied. In commercial operations, where it is to be expected that the quality of the canned pigeonpeas will always be lower than in the samples canned in the Laboratory, some other range of values may be found. The data here presented are intended to indicate the dependence of grade, and hence of the quality of canned pigeonpeas, on the maturity of the fresh product.

Since maturity determines the grade of the canned product it is pertinent now to determine the effect of maturity on shell-out percentage and yields 
in terms of cans produced. In table 2 the total shelled-out percentage and yields of No. 2 cans obtained when processing pigeonpeas at different stages of development are shown. Yields in terms of No. 2 cans produced are based

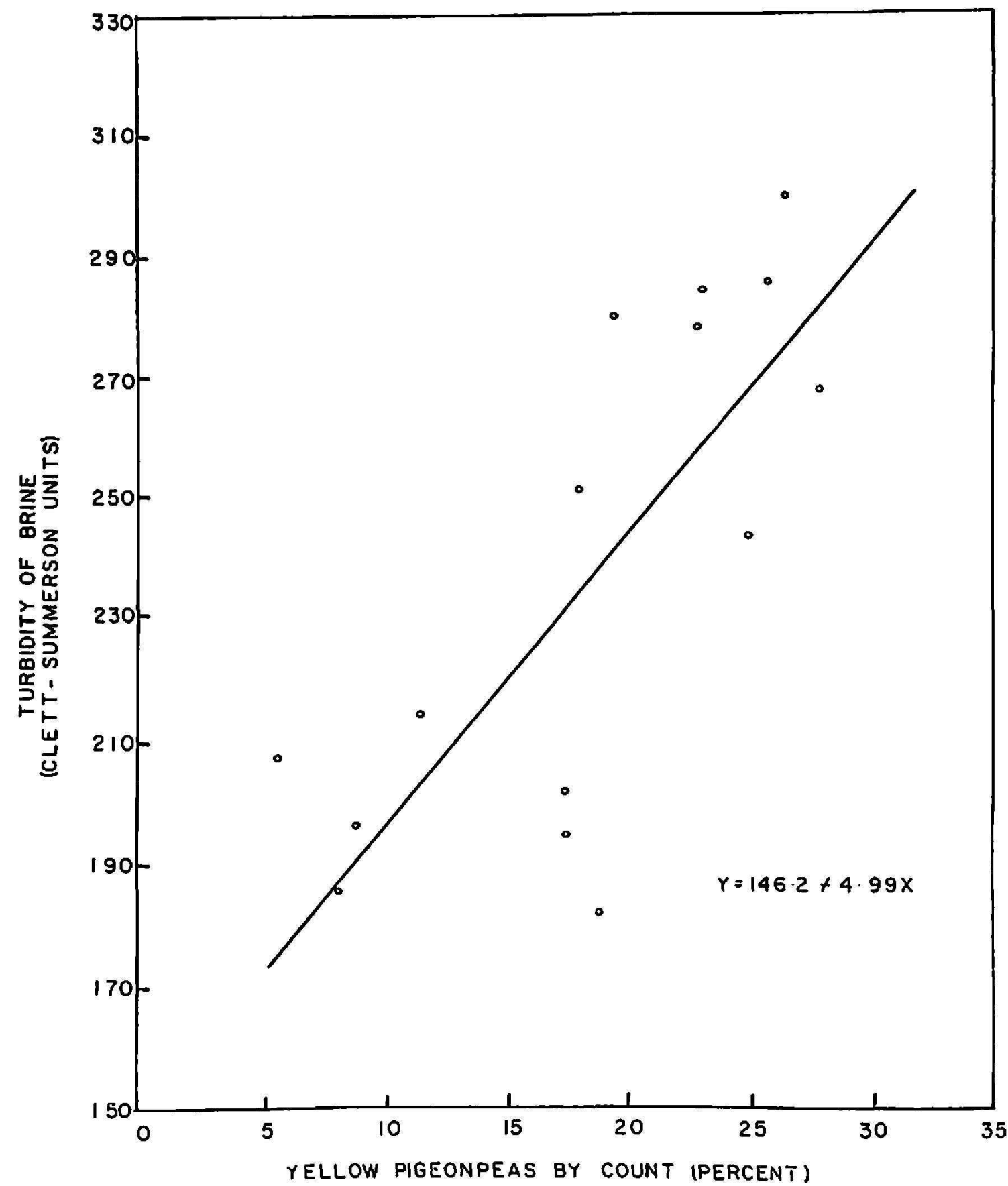

Fig. 5.-Relation between number of yellow pigeonpeas in the can and turbidity of the brine.

on the recovery of primary peas per 100 pounds of pods processed. As in all our experiments, the secondary peas, which are those of small size that go through the spacings of the rod-washers, are discarded. The data show that higher shelled-out percentage and higher yields of No. 2 cans are obtained 
when the peas become more mature. To obtain higher yields of peas it is necessary to process more mature peas, and this will result in a lowering of the quality of the product.

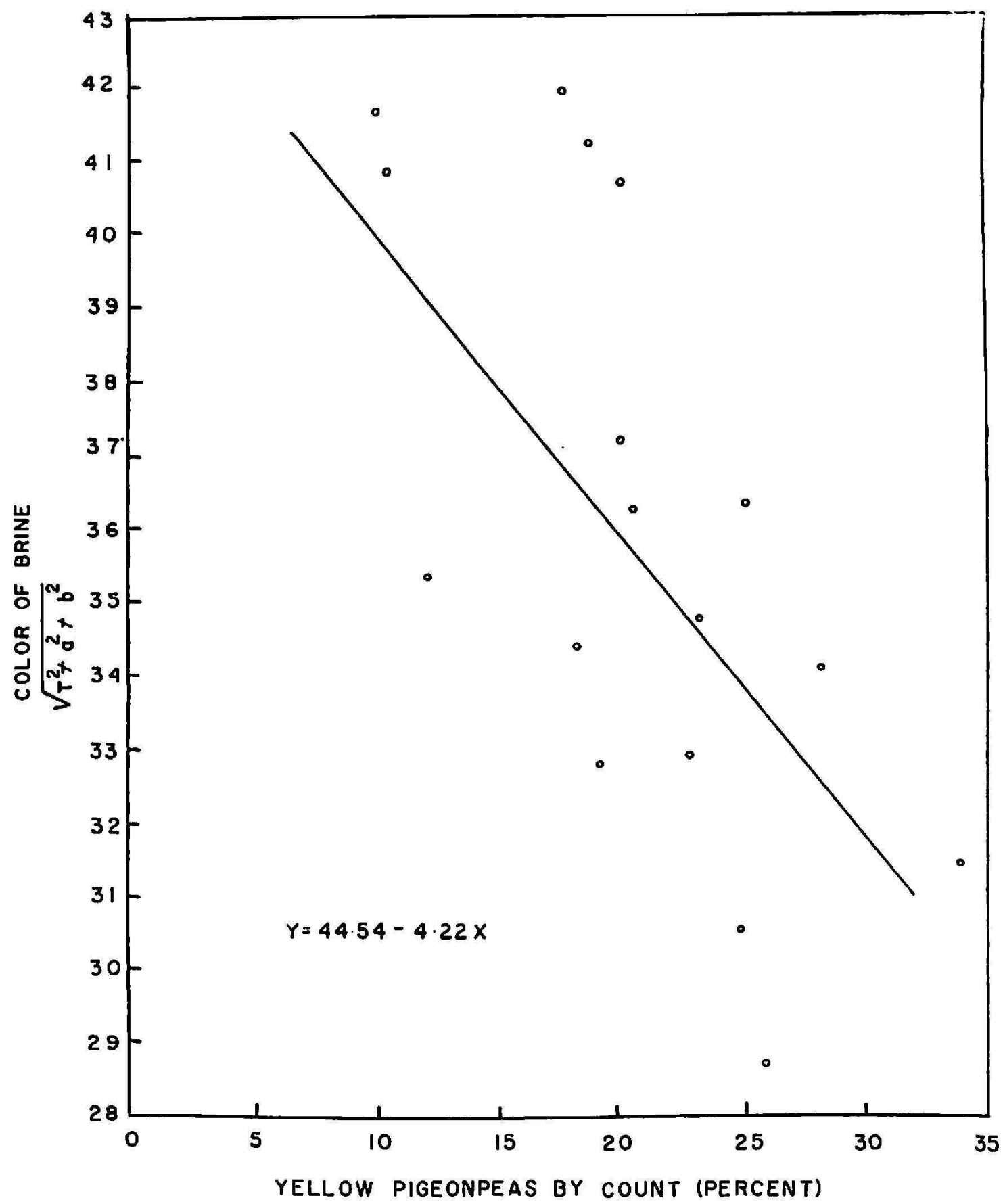

Fig. 6.-Relation between number of yellow pigeonpeas in the can and brine color.

In conditions under which the pigeonpea canning industry now operates where canners buy the raw peas on a weight basis, it is to be expected that yields obtained will receive particular attention, since the higher the yields the higher will be the net return to the processor. Under such a system quality becomes of secondary importance. Since the quality of the canned 
pigeonpeas is determined by the maturity, instead of buying pigeonpeas on a weight basis, a system should be established whereby pigeonpeas are sold on a quality basis, making it possible for canners to process pigeonpeas at the optimum stage of maturity and be able to can a product falling in the $A$ and $B$ classification and yet make a reasonable profit.

TABLE 4.-Grade-classification for pigeonpeas canned at different stages of malurity

\begin{tabular}{c|c|c|c|c|c}
\hline \multicolumn{2}{c|}{ Grade A } & \multicolumn{2}{c|}{ Grade B } & \multicolumn{2}{c}{ Grade C } \\
\cline { 1 - 2 } $\begin{array}{c}\text { Percentage of } \\
\text { yellow peas }\end{array}$ & A.I.S. & $\begin{array}{c}\text { Percentage of } \\
\text { yellow peas }\end{array}$ & A.I.S.1 & $\begin{array}{c}\text { Percentage of } \\
\text { yellow peas }\end{array}$ & A.I.S.1 \\
\hline 7.0 & 20.26 & 29.1 & 20.97 & 27.4 & 24.18 \\
6.7 & 20.92 & 22.4 & 22.32 & 19.0 & 23.83 \\
1.8 & 20.35 & 21.5 & 22.33 & 21.0 & 24.01 \\
2.3 & 20.49 & 23.2 & 24.49 & 34.3 & 24.33 \\
2.8 & 20.11 & 22.1 & 24.3 & 16.3 & 24.58 \\
1.96 & 19.65 & 27.7 & 23.29 & 20.6 & 23.77 \\
6.1 & 20.93 & 17.2 & 24.91 & 36.5 & 21.87 \\
8.6 & 19.74 & 11.1 & 21.90 & 17.0 & 25.67 \\
3.6 & 18.87 & 14.0 & 21.43 & 32.4 & 23.44 \\
2.3 & 20.56 & 20.0 & 24.02 & 32.6 & 24.30 \\
7.3 & 19.16 & 23.7 & 24.64 & & \\
& & 17.7 & 21.67 & & \\
& & 10.5 & 21.67 & & \\
\hline
\end{tabular}

${ }^{1}$ Alcohol-insoluble solids in canned pigeonpeas.

TABLE 5.-Dala in table 4 rearranged to show range of values for each grade

\begin{tabular}{c|c|c|c|c}
\hline \multirow{2}{*}{ Grade } & \multicolumn{2}{|c|}{ Yellow peas (percent) } & \multicolumn{2}{c}{ Alcohol-insoluble solids (percent) } \\
\cline { 2 - 3 } & Range of values & Mean value & Range of values & Mean value \\
\hline A & $1.8-8.6$ & 4.59 & $18.87-20.93$ & 20.09 \\
B & $10.5-29.1$ & 19.57 & $20.97-24.63$ & 22.93 \\
C & $16.3-36.5$ & 25.54 & $21.87-25.67$ & 23.90 \\
\hline
\end{tabular}

\section{SUMMARY}

The effect of maturity on the quality of canned pigeonpeas was studied. Various quality criteria such as drained weight, volume, and viscosity of the brine, color and turbidity of brine, and uniformity of color with respect to the predominance of green pigment were found to depend on the maturity of the pigeonpeas processed. It was found that higher drained weights were obtained as maturity increased. The viscosity of the brine increased while its volume decreased and the brine became darker and had a higher turbidity. Since all these quality criteria are taken into consideration in grad- 
ing the product, the maturity of the pigeonpeas being processed will determine the grade of the canned product.

Since higher shelled-out percentages are obtained as the pigeonpeas become more mature, processors may process peas at a stage of development which may lead to a lowering of the quality of the canned product. To insure a high-quality pack it is suggested that pigeonpeas should be bought by the processor according to quality or maturity, and not on a weight basis.

\section{RESUMEN}

Se llevó a cabo un estudio para determinar de qué modo la madurez del gandur afecta la calidad del producto cuando se envasa. Los datos obtenidos demuestran que el peso escurrido aumenta a medida que el grano está más maduro. La madurez excesiva del grano afecta también el volumen, la viscosidad, la turbiedad y el color de la salmuera.

Cuando se elaboran gandures en un grado de madurez excesiva, el volumen de la salmuera disminuye; la turbiedad y viscosidad aumentan y el color se oscurece. Esto no sucede cuando se envasan gandures mas tiernos.

No obstante, se ha comprobado que se obtienen rendimientos más altos cuando se envasan gandures maduros y que, además, es posible envasar mayor número de latas por quintal de producto. Sin embargo, se corre el riesgo de que se procese gandur en un grado tal de madurez que afecte la calidad óptima del producto elaborado. Para enlatar gandures de alta calidad-para lo cual es necesario envasar el grano en un estado de madurez menos avanzado-sugerimos que se establezca un sistema mediante el cual el gandur se compre según su madurez, no según su peso como acontece en la actualidad.

\section{LITERATURE CITED}

1. Sánchez-Nieva, F., Rodríguez, A. J., Benero, J. R., Improved Method of Canning Pigeonpeas, Bul. 157, Agr. Exp. Sta., Univ. of P.R., 1961.

2. Sánchez-Nieva, F., González, M. A., Benero, J. R., The effect of some processing variables on the quality of canned pigeonpeas, J. Agr. Univ. P.R. 45 (4) 232-58, 1961.

3. Makower, R. U., Methods of measuring the tenderness and maturity of processed peas, Food Tech. 4 403-8, 1950.

4. Malcolm, H. R., Powers, J. J., López, A., Pratt, D., Objective measurements of the maturity of raw canned field peas, Food Tech. 10 463-9, 1959.

5. Woodruff, J. G., Canning southern field peas, South. Canr. and Pack., 12 (5) 6, 1951.

6. Kramer, A., Relation of maturity to yield and quality of raw and canned peas, corn and lima beans, Am. Soc. Hort. Sci. 47 361-7, 1946.

7. Sánchez-Nieva, F., Cancel, M. M., Benero, J. R., Maturity indices for pigeonpeas, J. Agr. Univ. P.R. 44 60-9, 1960.

8. Official Methods of Analysis, Assn. Agr. Chem., Washington, D.C., 8th ed., 572, 1955. 